\title{
頭部外傷に対する低体温療法の適応と限界
}

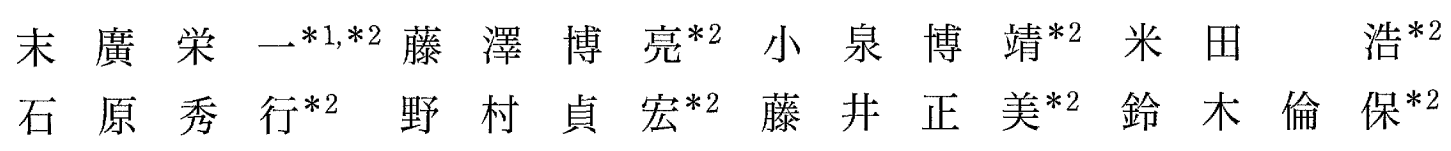

\section{Application and Limitations of Hypothermia Therapy for Traumatic Brain Injury}

by

Eiichi Suehiro, M.D. ${ }^{* 1, * 2}$, Hirosuke Fujisawa, M.D. ${ }^{* 2}$, Hiroyasu Koizumi, M.D. ${ }^{* 2}$, Hiroshi Yoneda, M.D. ${ }^{* 2}$, Hideyuki Ishihara, M.D. ${ }^{* 2}$, Sadahiro Nomura, M.D. ${ }^{* 2}$, Masami Fujii, M.D. ${ }^{* 2}$, and Michiyasu Suzuki, M.D. ${ }^{* 2}$

from

${ }^{* 1}$ Department of Neurosurgery, Kenwakai Ohtemachi Hospital

*2Department of Neurosurgery, Yamaguchi University School of Medicine

No treatment method for severe traumatic brain injury (TBI) has proven effective to replace hypothermia therapy, emphasizing the major role of this therapy for patients with TBI. To improve the effectiveness of hypothermia therapy, earlier hypothermia induction is necessary, and management of brain temperature should be based on individual pathophysiology through neuromonitoring during the maintenance and rewarming periods of this therapy. Recently, the protective effects of hypothermia therapy have been confirmed for patients with severe TBI after craniotomy. The outcome of TBI patients with hypothermia therapy is expected to improve with the use of the brain temperature management method and selection of appropriate pathophysiology.

(Received July 1, 2011; accepted August 8, 2011)

Key words : traumatic brain injury, hypothermia, neuromonitoring, brain temperature

Jpn J Neurosurg（Tokyo）20:873-879, 2011

\section{はじめに}

頭部外傷後早期には，血腫などの占拠性病変のみなら ず，呼吸・循環障害など全身性要素による脳血流代謝異 常が二次性脳損傷の進展へと関与し, 転㷌に大きく寄与 する ${ }^{128)}$ ．頭部外傷治療の主な目的は，この二次性脳損 傷をできるだけ抑制し，頭部外傷患者の転帰改善につな げることである。しかし，近年の本邦における傾向とし ては，一次性脳損傷が大きい重症例に刘して治療成績も 良好とは言えないため, 二次性脳損傷に対する治療法の
選択やゴールを熟慮せず容易に治療を断念してしまう傾 向がある，低体温療法の目的は，まさにこの二次性脳損 傷を抑制することに他ならない.

本法の歴史を振り返ると, 1993 年に頭部外傷に対する 脳保護効果に関する臨床研究が相次いで報告され て ${ }^{6) 25) 37)}$ 世界的に注目を浴びたが, 2001 年には多施設無 作為対照臨床研究 (NABIS：H）において有意な効果が 認められず7), 現在は積極的に起用される治療法とは言 い難い。しかし，その後も重症頭部外傷治療において低 体温療法に代わる有效な治療法は出現せず, 手詰まり感

\footnotetext{
*1健和会大手町病院脳神経外科 / $\bar{T} 803-8543$ 北九州市小倉北区大手町 15-1〔連絡先: 末廣栄一〕

Address reprint requests to: Eiichi Suehiro, M.D., Department of Neurosurgery, Kenwakai Ohtemachi Hospital, 15-1 Ohte-machi, Kokurakita-ku, Kitakyushu-shi, Fukuoka 803-8543, Japan

${ }^{* 2}$ 山口大学医学部脳神経外科
} 
が強いのが現状である、そのためわれわれは，重症頭部 外傷の治療成績を改善させるべく, 低体温療法の適応や 管理方法を試行錯誤している，本稿では，低体温療法の 歴史的背景を振り返りながら基礎研究・臨床研究を review し，低体温療法の適応や管理法についての現状と 今後の展望について考察する.

\section{低体温療法の歴史的背景}

低体温療法の歴史は, ギリシア時代に Hippocrates が 皮膚切開の前に局所表面冷却を行い麻酔として使用した のが始めとされている ${ }^{12)}$.また, 1938 年には Temple Fay (1895-1963) ${ }^{111}$ が初めて全身冷却という手法で悪性腫瘍 の増悪の抑制と除痛を目的に低体温療法を行った，第二 次世界大戦後, 心臟手術の分野で低体温の導入が模索さ れるようになり，この頃から低体温と脳損傷の関係につ いて論議されるようになった. 1956 年，イヌの中大脳動 脈結禁モデルを用いて， $25^{\circ} \mathrm{C}$ 以下にて脳梗塞巣の体積が 有意に減少することを示した ${ }^{35)}$ のが，低体温療法の脳保 護効果についての初めての報告と思わ机る。1960１970 年代にかけて，凍った川や池に溺水した後の蘇生例にお いて転㷌良好例が報告され23340)，低体温の脳保護作用が 次第に注日されるようになった。しかし，現在ほど全身 管理の技術や知識が豊富でない当時は，循環障害や感染 症など臨床的な合併症が前面に立ち，いったんは低体温 療法は影を潜めてしまった。その後 1987 年には, $32^{\circ} \mathrm{C}$ の軽微低体温療法によって脳虚血モデルでの脳保護効果 を示寸報告があり ${ }^{2)}$ ，全身合併症を最小限にとどめる管 理が可能な体温であったことから，低体温療法が再び注 日を集めるターニングポイントとなった。同時期，重症 急性硬膜下血腫の偶発的低体温例における転帰良好例が 報告され ${ }^{42)}$ ，頭部外傷でも低体温療法が注目されるよう になった. 1991 年には, 実験的頭部外傷モデルにて低体 温療法の脳保護效果が報告され ( $^{5)}$ ，世界各国に頭部外傷 に対する低体温療法の臨床的応用が広がることとなっ た. 1993 年には米国ならびに日本から相次いで，頭部外 傷に対する低体温療法の良好な結果を示した臨床研究が 報告されて625)37)脚光を浴びた．以降，頭部外傷に対す る低体温療法に関して，基礎的ならびに臨床的研究が数 多〈報告された 4)7710)13) 14)22（24)27)32) 41145)50)，低体温療法の 作用機序として，グルタミン酸放出の抑制のみならず， さまざまな機序が報告された。いずれの作用機序も受傷 後早期から低体温療法の導入が必要とされるものであ る。受傷後治療導入が遅れた例でも，低体温時間の延長 や緩やかな復温にて脳保護効果を拡大する報
告4) 13) 14)26)43)もみられ, 以後の臨床応用に大きなヒント を与えている，その後，低体温療法の頭部外傷治療にお ける evidence を求めて大規模臨床研究が 1994 年から開 始された。良好な結果が期待されたが, 2001 年の Clifton $ら^{7)}$ の報告では，頭部外傷に対して低体温療法の有効性 が認められず，再び衰退の一途をたどることとなった。

\section{低体温療法の作用機序と合併症}

低体温療法の作用機序には，多くの二次性脳損傷抑制 に関与した機序が含まれる。グルタミン酸放出の抑制3) やカルシウム依存性カスケード反応の抑制 ${ }^{29)}$, 脳代謝の 抑制 ${ }^{52}$, 活性酸素や NO 産生の抑制 ${ }^{18219)}$ ，アポトーシス の抑制 512 ，血液脳関門破綻の抑制 41 などが報告されてい る. 重症頭部外傷治療に低体温療法を導入する際は, こ れらの機序を念頭に置いて適切な管理を行う必要があ る.

また，低体温療法の導入による多くの合併症が報告さ れている. 感染症 (免疫能低下) や電解質異常（低力リ ウム血症), 血小板滅少などの他に, 体温低下に伴い不整 脈の出現や心拍出量の低下，それに伴う代謝性アシドー シスなど, 循環器領域に関連した合併症も多い。さらに は，肝機能障害や腎機能障害，消化管機能障害，高血糖 などである。冷却温度が低いほど，維持時間が長いほど 合併症の頻度は高いとされている. Tokutomi ら ${ }^{48)}$ は, 33 ${ }^{\circ} \mathrm{C}$ と $35^{\circ} \mathrm{C}$ の低体温療法を比較し, $35^{\circ} \mathrm{C}$ で合併症の発現 率が有意に減少し, 低体温療法による効果は $33^{\circ} \mathrm{C}$ と変わ りないと報告した。 それ以降, 低体温療法では $34^{\circ} \mathrm{C}$ ある いは $35^{\circ} \mathrm{Cで}$ 管理する施設が多い。この温度であれば，肺 理学療法や口腔ケアなどの肺炎予防策と厳重な全身管理 を行えば，深刻な合併症に陥ることは少ない．

\section{低体温療法の脳温管理}

\section{[1 導入時間}

低体温療法への導入時間は，ょり早期が望まれる。低 体温療法の作用機序は, 当初損傷により誘発されるグル 夕ミン酸放出の抑制が主であると考元られ，受傷前から の pre-treatment でのみ効果を有すると考光られてい た。しかし，受傷後からの post-treatment でも脳保護効 果が認められるようになった4)51024)ため臨床応用へと 発展した。しかし，大多数の実験モデルでは，受傷直後 あるいは受傷後 10 分程度にて低体温療法が導入されて おり,この点で実験モデルと臨床応用との間に乘離があ る。臨床的には Clifton $ら^{7)}$ による NABIS：H において, 
低体温療法は有意な脳保護効果を認めることができな かった。彼らはその二次解析の中で，低体温の導入時期 の観点から搬入時に偶発的低体温であった患者群に注目 した ${ }^{8)}$.45 歳以下の搬入時から偶発的低体温であった患 者群においては，平温療法群での予後不良率が $76 \%$ で あったのに対し，低体温療法群では $52 \%$ と有意に低下し ていた ${ }^{8)}$ 。つまり, 早期の導入こそが低体温療法の脳保 護効果を引き出す要素であると考えた。このデー夕を根 拠に, Clifton ら ${ }^{9)}$ は 2005 年より新しい臨床研究を開始し た（NABIS：H II ). 患者の選択基準を 16〜45 歳の若年 者とし, 受傷後 2.5 時間以内に臨床研究登録可能な症例 とした ${ }^{9)}$. その結果, 平均 4.4 時間で $33^{\circ} \mathrm{C}$ まで泠却完了 が成されていた9)。しかし, 最終的な転帰では, 平温療 法群で予後不良率が $56 \%$, 低体温療法群で $60 \%$ と有意 な脳保護効果を認めることができなかった ${ }^{9)}$. 基礎研究 では，低体温療法の脳保護効果に関して多くの肯定的 データが報告されているのに対して, 臨床研究で evidence が得られないのは, 受傷後超早期の低体温導入が 困難である可能性がある．現在の臨床現場では NABIS： H II で示された受傷後 4 時間前後の低体温療法への導入 が限界值ではないかと考完られる。日本では病院前救急 診療として，早期医療介入による救命率の向上と転㷌改 善を目的として，ドクターヘリの運行が開始された。 2010 年 10 月現在, 19 道府県 23 力所に配置され ${ }^{21)}$, さ らなる運行規模の拡大をみせている。重症頭部外傷患者 においても, 頭部外傷の二次性脑損傷の要因である低酸 素血症や低血圧へ早期に対応し，転帰良好例が有意に多 いと報告されている ${ }^{36)}$. 今後, このような病院前救急医 療の改善により, 治療開始時間の短縮と早期の低体温療 法への導入が期待される。

\section{2 維持時間}

実験的頭部外傷モデルで低体温療法の有效性を示した 報告では，その維持時間は 1 時間であった5)。その後の 報告では, 低体温療法の維持時間は 3 6 時間と長期化

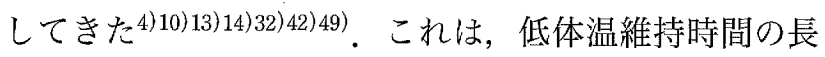
い条件が脳保護効果に優れていた解析結果のためと思わ れる。臨床的には，それまで低体温療法の維持時閒は， 多くの報告で 24 時間あるいは 48 時間であった ${ }^{727)}$ 。し

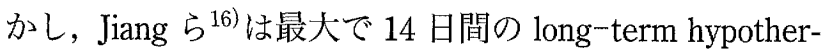
mia を施行し, 良好な治療成績を報告した。受傷後 1 年 時の予後良好率は, 平温療法群 $27.27 \%$ に対して低体温 療法群では 46.51\%まで有意に改善した ${ }^{16)}$ 。また彼らは, 低体温療法の維持時間が 2 日間の short-term hypothermia と 5 日間の long-term hypothermia の受傷後 6 力月

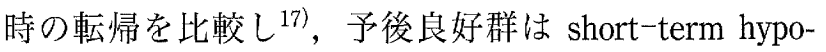
thermia で $29.0 \%$ に対して long-term hypothermia では $43.5 \%$ と有意な改善を報告した ${ }^{17}$. これらより, 低体温 療法は長時間低体温を維持するほど脳保護効果は期待で きると思わ扎るが，合併症の増加が危惧される．脳保護 効果と合併症抑制をにらんだ適正な維持時間が最重要課 題であり, 頭蓋内压 (ICP) センサーなどの頭蓋内環境 のモニタリングが必須である. Cochrane review では, 成 人の頭部外傷に対する低体温療法の 8 つの大規模臨床 研究が検討されている ${ }^{46)}$ ：モニタリングなしでプロト コールどおりに 1 2 日低体温療法を実施し，そのまま 復温を開始した臨床研究は 3 つ, ICP をモニタリングし て正常化された後に復温し, 結果的に 3〜5 日間の低体 温療法となった臨床研究が $5 つ$ つた。この review 中, 低体温療法の有効性は前者では皆無であったが, 後者 5 つ中 4 つで改善が示された ${ }^{9)}$.また, Murakami ら ${ }^{30)}$ は, 搬 入時 Glasgow Coma Scale（GCS）3 で両側瞳孔散大した 最重症例に対して, ICP モニタリング下に ICP が正常化 する 28 日後まで低体温療法を継続し, 会話や歩行可能 なまでに改善した例を報告している，すなわち，低体温 療法の維持時間には至適時間はなく, モニタリング下に 個々の症例の病態に応じて個別化されるべきである，現 時点では ICP のモニタリングが適当かと思われるが，今 後さまざまなモニタリング下で検討する余地がある。ま た, 維持時間が長期化する場合, 合併症の低減がもう一 つの課題となる.

\section{3 復 温}

1997 年の Marion ら ${ }^{27)}$ の臨床研究において, 入院時偶 発的低体温であった患者群中平温療法群に割り付けられ た患者群の転㷌不良は $66 \%$ と高率であった（2001 年の Clifton らの臨床研究では同じ条件にて $52 \%)^{7)}$. 本研究 では偶発的低体温例に対して積極的に復温したことが理


に低体温療法の復温法が重要視されるようになった。そ の後, 実験的頭部外傷モデルにおいても, 急速な復温に より脳損傷や微小脳循環を増悪させるデータが示され た ${ }^{33) 43) 44)}$. また，臨床的にも入院時偶発的低体温であっ た頭部外傷患者についての復温は慎重に行うべきであ る，あるいは急速な復温によって転帰を増悪させるとの 報告が相次いだ20)47). その機序として, 復温中の脳血流 と脳代謝の不均衡や脳血管反応性の傷害による微小脳循 環障害が基礎実験では認められている31)44)。臨床的にも 復温中に hyperemia, 続いて急性脳腫脹を認めた報告が ある ${ }^{15)}$ 。つまり復温中は脳循環代謝が不安定であり，こ 


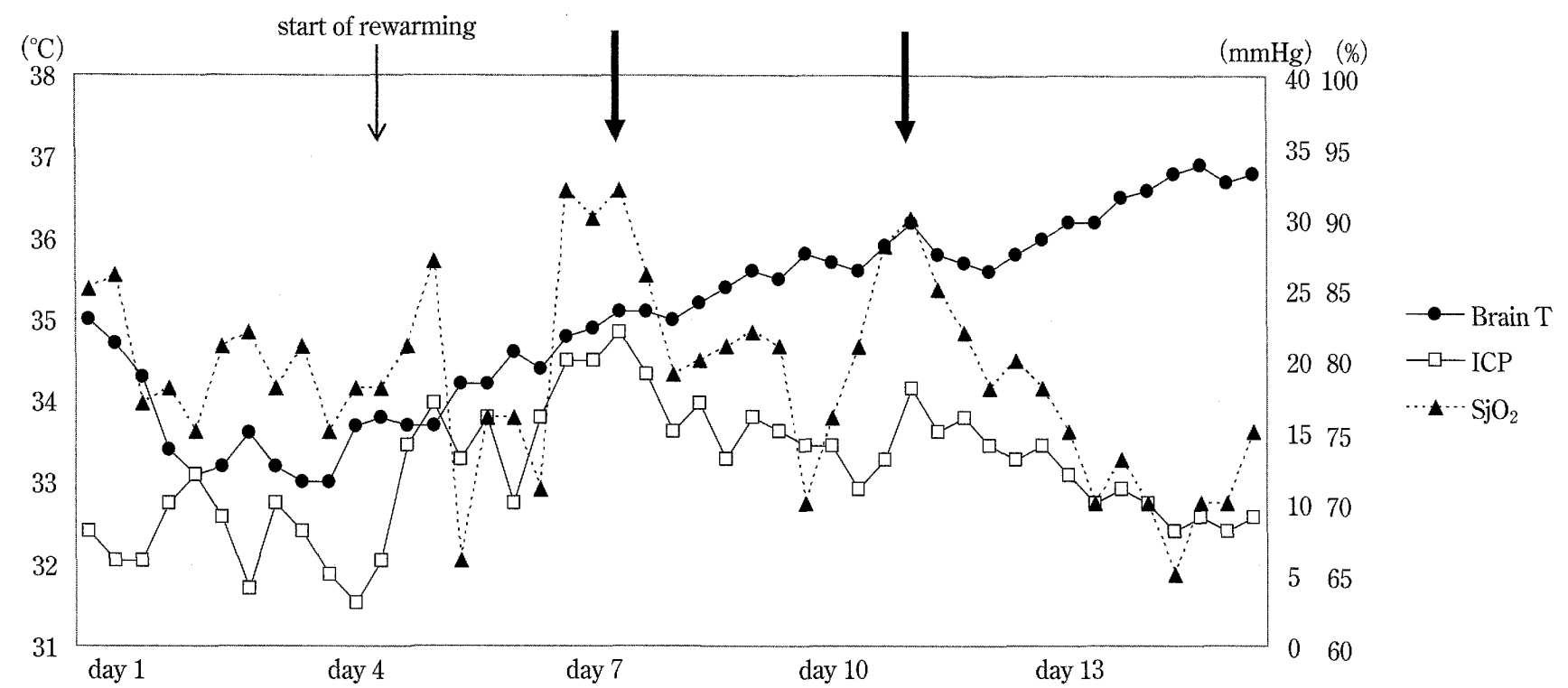

Fig. 1 Graph showing changes in neuromonitoring of our case during hypothermia therapy. The rapid rises of intracranial pressure (ICP) following the rises of jugular venous oxygen saturation $\left(\mathrm{SjO}_{2}\right)$ happened twice during rewarming period of hypothermia therapy (arrow).

のステージでも頭蓋内環境のモニタリングが重要であ る。われわれの施設では, 低体温療法導入から復温が完 了するまで, 全例で ICP ならびに内頝静脈球酸素飽和度 $\left(\mathrm{SjO}_{2}\right)$ をモニターしている. 61 歳女性の低体温療法導

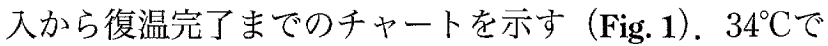
72 時間の低体温療法を施行し， $0.5^{\circ} \mathrm{C} /$ 日の割合でゆっく りと復温した。しかし，復温中に $\mathrm{SjO}_{2}$ が上昇し，続いて ICP が上昇する現象が 2 回発生した。その際，復温を いったん中止する，あるいは $0.5^{\circ} \mathrm{C}$ 脳温を下げることに より，ICP は正常範閁へ戻り復温を再開することができ た。緩徐な復温は転帰改善のために重要な要素であるが, 盲目的に行うのではなく，モニタリング下に脳循環代謝 を同時に把握することが必須である。

\section{頭部外傷の病態別にみた低体温療法の適応}

頭部外傷に対する低体温療法の適応基準は，多くの臨 床研究で GCS score 8 以下の重症頭部外傷となってい る。しかし，重症頭部外傷の病態は多様で，ICP 六進の 有無, びまん性軸索損傷, 急性硬膜下血腫, 脳挫傷なぞ, さまざまな病態が含まれる。低体温療法の導入は，それ ぞれの病態に対して異なった治療効果がある。そのため 評価の際には, その多様な群を一括して行うことは困難 であり，病態別に解析する必要がある。 Shiozaki ら ${ }^{38}$ に よれば，ICP 兄進を伴う重症頭部外傷に対して低体温療 法を導入し, 外傷性脳出血/脳挫傷では $85 \%$, 硬膜下 (外) 血腫では $88.9 \%$ の症例で ICP の制御が可能であった。し
かしびまん性脳腫脹の症例では全例で ICP の制御が不 可能であった ${ }^{38)}$ ．また，逆に ICP 六進を伴わない重症頭 部外傷については, 低体温療法の治療効果を認めること ができなかった ${ }^{39)}$.

近年急性硬膜下血腫や脳挫傷など，開頭術を要する頭 部外傷に対し，低体温療法が注目されている，Qiu ら ${ }^{34)}$ の開頭術施行例の検討において, 受傷後 72 時間後の ICP が平温療法群では $24.57 \pm 3.95 \mathrm{mmHg}$ であるのに対 して，低体温療法群では $22.51 \pm 2.44 \mathrm{mmHg}$ と有意に低 下していた。 また，受傷後 1 年時の転帰良好率は，平温 療法群の $47.5 \%$ に対して, 低体温療法群では $70.0 \%$ と有 意に高かった ${ }^{34)}$ ，同様の結果が NABIS：HIIでも示され ている ${ }^{9)}$. Diffuse brain injury 群では，予後不良率が平温 療法群で $50 \%$, 低体温療法群で $70 \%$ と有意差は認めら れていないが, surgically removed haematoma 群では, 予 後不良率が平温療法群で $69 \%$ に対して低体温療法群で は33\%と，有意差をもって低下している9，日本におけ る頭部外傷への低体温療法に関する多施設無作為対照臨 床研究（BHYPO）においても, 同様の結果が示されてい るようである (personal communication)。これらの患者 は, 開頭時にはすでに低体温療法が導入されているため, 減圧時に発生する反応 (再灌流によるフリーラジカルの 発生など）が高率に抑制されるのではないかと推測され る. 今後 focal injury における低体温療法の有效性に関す る作用機序についての検討が必要である. 


\section{おわりに}

本稿では，頭部外傷に対する低体温療法の管理法や適 応症例について review した。これまで, 頭部外傷に対す る低体温療法に関して, 数多くの基礎的・臨床的研究が 報告されているが，頭部外傷ではさまざまな病態が存在 するため，実際に鑒床応用する際には基礎的研究の病態 とは異なる条件となることが多い，そのため，各施設が 低体温療法の温度管理法をそれぞれ工夫している。結果 的に各施設間で低体温療法の温度管理法や治療成績に差 が生じている。この問題を解消するためには，モニタリ ングを指標とした個々の症例の病態に対応した脳温管理 が必要と考える。そのためには，最適なモニタリングと 目標值の設定などを，さらに検証し標準的な脳温管理法 を確立することが必要である。

昨今，頭部外傷の病態別に治療効果が異なっているこ とが明らかになってきた。今後も臨床研究を通して頭部 外傷の病態別治療成績を継続評価し，適応症例の詳細を 解明していかなければならない.

\section{文 献}

1) Bouma GJ, Muizellaar JP, Choi SC, Newlon PG, Young $\mathrm{HF}$ : Cerebral circulation and metabolism after severe traumatic brain injury: The elusive role of ischemia. $J$ Neurosurg 75:685-693, 1991.

2) Busto R, Dietrich WD, Globus MY, Valdés I, Scheinberg P Ginsberg MD: Small differences in intraischemic brain temperature critically determine the extent of ischemic neuronal injury. J Cereb Blood Flow Metab 7: 729-738, 1987.

3) Busto R, Globus MY, Dietrich WD, Martinez E, Valdés I, Ginsberg MD : Effect of mild hypothermia on ischemiainduced release of neurotransmitters and free fatty acids in rat brain. Stroke 20:904-910, 1989.

4) Clark RS, Kochanek PM, Marion DW, Schiding JK, White M, Palmer AM, DeKosky ST: Mild posttraumatic hypothermia reduces mortality after severe controlled cortical impact in rats. J Cereb Blood Flow Metab 16:253-261, 1996

5) Clifton GL, Jiang JY, Lyeth BG, Jenkins LW, Hamm RJ, Hayes RL: Marked protection by moderate hypothermia after experimental traumatic brain injury. J Cereb Blood Flow Metab 11: 114-121, 1991.

6) Clifton GL, Allen S, Barrodale P, Plenger P, Berry J, Koch S, Fletcher J, Hayes RL, Choi SC: A phase II study of moderate hypothermia in severe brain injury. J Neurotrauma 10:263-271, 1993.

7) Clifton GL, Miller ER, Choi SC, Levin HS, McCauley S, Smith KR Jr, Muizelaar JP, Wagner FC Jr, Marion DW, Luerssen TG, Chesnut RM, Schwartz M: Lack of effect of induction of hypothermia after acute brain injury. $N$ Engl J Med 344: 556-563, 2001.

8) Clifton GL, Miller ER, Choi SC, Levin HS, McCauley S, Smith KR Jr, Muizelaar JP, Marion DW, Luerssen TG:
Hypothermia on admission in patients with severe brain injury. J Neurotrauma 19:293-301, 2002.

9) Clifton GL, Valadka A, Zygun D, Coffey CS, Drever P, Fourwinds S, Janis LS, Wilde E, Taylor P, Harshman K, Conley A, Puccio A, Levin HS, McCauley SR, Bucholz RD, Smith KR, Schmidt JH, Scott JN, Yonas H, Okonkwo DO : Very early hypothermia induction in patients with severe brain injury (the National Acute Brain Injury Study : Hypothermia II ) : A randomized trial. Lancet Neurol 10: 131-139, 2011.

10) Dietrich WD, Alonso O, Busto R, Globus MY, Ginsberg $\mathrm{MD}$ : Post-traumatic brain hypothermia reduces histopathological damage following concussive brain injury in the rat. Acta Neuropathol 87:250-258, 1994.

11) Fay $T$ : Early experiences with local and generalized refrigeration of the human brain. J Neurosurg 16:239260, 1959.

12) Furnas DW: Annals of history. Topical refrigeration and frost anesthesia. Anesthesiology 26:344-347, 1965.

13) Globus MY, Alonso O, Dietrich WD, Busto R, Ginsberg $\mathrm{MD}$ : Glutamate release and free radical production following brain injury: Effects of posttraumatic hypothermia. $J$ Neurochem 65: 1704-1711, 1995.

14) Goss JR, Styren SD, Miller PD, Kochanek PM, Palmer AM, Marion DW, DeKosky ST: Hypothermia attenuates the normal increase in interleukin 1 beta RNA and nerve growth factor following traumatic brain injury in the rat. $J$ Neurotrauma 12: 159-167, 1995.

15) Iida $K$, Kurisu $K$, Arita $K$, Ohtani $M$ : Hyperemia prior to acute brain swelling during rewarming of patients who have been treated with moderate hypothermia for severe head injuries. J Neurosurg 98: 793-799, 2003.

16) Jiang J, Yu M, Zhu C: Effect of long-term mild hypothermia therapy in patients with severe traumatic brain injury : 1-year follow-up review of 87 cases. $J$ Neurosurg 93: $546-549,2000$.

17) Jiang JY, Xu W, Li WP, Gao GY, Bao YH, Liang YM, Luo QZ: Effect of long-term mild hypothermia or short-term mild hypothermia on outcome of patients with severe traumatic brain injury. $J$ Cereb Blood Flow Metab 26: 771776, 2006.

18) Kader A, Frazzini VI, Baker CJ, Solomon RA, Trifiletti $\mathrm{RR}$ : Effect of mild hypothermia on nitric oxide synthesis during focal cerebral ischemia. Neurosurgery 35:272277, 1994.

19) Kil HY, Zhang J, Piantadosi CA: Brain temperature alters hydroxyl radical production during cerebral ischemia/ reperfusion in rats. J Cereb Blood Flow Metab 16:100106, 1996.

20) Kinoshita K, Utagawa A, Ebihara T, Furukawa M, Sakurai A, Noda A, Moriya T, Tanjoh K : Rewarming following accidental hypothermia in patients with acute subdural hematoma: case report. Acta Neurochir Suppl 96:4447, 2006.

21）小林誠人：頭部外傷を含む外傷におけるドクターカー, ドクターヘリの有用性。救急医学 34: 1741-1743, 2010.

22) Koizumi H, Povlishock JT: Posttraumatic hypothermia in the treatment of axonal damage in an animal model of traumatic axonal injury. J Neurosurg $89: 303-309,1998$.

23) Kvittingen TD, Naess $A$ : Recovery from drowning in fresh water. Br Med J 1: 1315-1317, 1963. 
24) Lyeth BG, Jiang JY, Liu S: Behavioral protection by moderate hypothermia initiated after experimental traumatic brain injury. J Neurotrauma 10: 57-64, 1993.

25) Marion DW, Obrist WD, Carlier PM, Penrod LE, Darby JM: The use of moderate therapeutic hypothermia for patients with severe head injuries: A preliminary report. $I$ Neurosurg 79:354-362, 1993.

26) Marion DW, White MJ: Treatment of experimental brain injury with moderate hypothermia and 21-aminosteroids. J Neurotrauma 13:139-147, 1996.

27) Marion DW, Penrod LE, Kelsey SF, Obrist WD, Kochanek PM, Palmer AM, Wisniewski SR, DeKosky ST: Treatment of traumatic brain injury with moderate hypotherma. N Engl J Med 336: 540-546, 1997.

28) Maxwell WL, Irvine A, Adams JH, Graham DI, Gennarelli TA: Response of cerebral microvasculature to brain injury. J Pathol 155:327-335, 1988.

29) Mitani A, Kadoya F, Kataoka K: Temperature dependence of hypoxia-induced calcium accumulation in gerbil hippocampal slices. Brain Res 562: 159-163, 1991.

30) Murakami $M$, Tsukahara $T$, Ishikura $H$, Hatano $T$, Nakakuki T, Ogino E, Aoyama T: Successful use of prolonged mild hypothermia in a patient with severe head injury and diffuse brain swelling. Case report. Neurol Med Chir (Tokyo) 47:116-120, 2007.

31) Nakamura T, Miyamoto O, Yamagami S, Hayashida Y, Itano $\mathrm{T}$, Nagao $\mathrm{S}$ : Influence of rewarming conditions after hypothermia in gerbils with transient forebrain ischemia. $J \mathrm{Neu}$ rosurg 91: 114-120, 1999.

32) Palmer AM, Marion DW, Botscheller ML, Redd EE: Therapeutic hypothermia is cytoprotective without attenuating the traumatic brain injury-induced elevations in interstitial concentrations of aspartate and glutamate. $J$ Neurotrauma $10: 363-372,1993$.

33) Povlishock JT, Wei EP: Posthypothermic rewarming considerations following traumatic brain injury. $J$ Neurotrauma 26: $333-340,2009$.

34) Qiu W, Zhang Y, Sheng H, Zhang J, Wang W, Liu W, Chen $\mathrm{K}$, Zhou J, Xu Z: Effects of therapeutic mild hypothermia on patients with severe traumatic brain injury after craniotomy. J Crit Care 22:229-235, 2007.

35) Rosomoff HL: Hypothermia and cerebral vascular lesions. I. Experimental interruption of the middle cerebral artery during hypothermia. J Neurosurg 13:332-343, 1956.

36）塩見直人，宮城知也，香月裕志，前田充秀，重森 稔， 山下典雄, 坂本照夫：重症頭部外傷初期診療におけるド ク夕ーヘリの有用性. 日救急医会誌 17:219-226, 2006.

37) Shiozaki T, Sugimoto H, Taneda M, Yoshida H, Iwai A, Yoshioka T, Sugimoto T: Effect of mild hypothermia on uncontrollable intracranial hypertension after severe head injury. J Neurosurg 79:363-368, 1993.

38) Shiozaki $T$, Sugimoto $H$, Taneda $M$, Oda J, Tanaka $H$, Hiraide A, Shimazu T: Selection of severely head injured patients for mild hypothermia therapy. $J$ Neurosurg 89 : 206-211, 1998.

39) Shiozaki T, Kato A, Taneda M, Hayakata T, Hashiguchi N,
Tanaka H, Shimazu T, Sugimoto H: Little benefit from mild hypothermia therapy for severely head injured patients with low intracranial pressure. J Neurosurg 91 : 185-191, 1999.

40) Siebke H, Rod T, Breivik H, Link B : Survival after 40 minutes; submersion without cerebral sequelae. Lancet 1: 1275-1277, 1975.

41) Smith SL, Hall ED : Mild pre- and posttraumatic hypothermia attenuates blood-brain barrier damage following controlled cortical impact injury in the rat. $J$ Neurotrauma 13:1-9, 1996.

42) Strachan RD, Whittle IR, Miller JD: Hypothermia and severe head injury. Brain Inj $\quad 3: 51-55,1989$.

43) Suehiro E, Povlishock JT: Exacerbation of traumatically induced axonal injury by rapid posthypothermic rewarming and attenuation of axonal change by cyclosporine A. $J$ Neurosurg 94: 493-498, 2001.

44) Suehiro E, Ueda Y, Wei EP, Kontos HA, Povlishock JT: Posttraumatic hypothermia followed by slow rewarming protects the cerebral microcirculation. $J$ Neurotrauma 20:381-390, 2003.

45) Suehiro E, Fujisawa H, Akimura T, Ishihara H, Kajiwara K, Kato S, Fujii M, Yamashita S, Maekawa T, Suzuki M: Increased matrix metalloproteinase -9 in blood in association with activation of interleukin -6 after traumatic brain injury: Influence of hypothermic therapy. $J$ Neurotrauma 21: 1706-1711, 2004.

46) Sydenham E, Roberts I, Alderson P: Hypothermia for traumatic head injury. Cochrane Database Syst Rev 2: CD001048, 2009.

47) Thompson HJ, Kirkness CJ, Mitchell PH: Hypothermia and rapid rewarming is associated with worse outcome following traumatic brain injury. I Trauma Nurs 17:173177, 2010.

48) Tokutomi T, Miyagi T, Takeuchi Y, Karukaya T, Katsuki H, Shigemori M: Effect of 35 degrees $\mathrm{C}$ hypothermia on intracranial pressure and clinical outcome in patients with severe traumatic brain injury. J Trauma 66:166-173, 2009.

49) Ueda Y, Wei EP, Kontos HA, Suehiro E, Povlishock JT: Effects of delayed, prolonged hypothermia on the pial vascular response after traumatic brain injury in rats. $J$ Neurosurg 99: 899-906, 2003.

50) Whalen MJ, Carlos TM, Clark RS, Marion DW, DeKosky MS, Heineman S, Schiding JK, Memarzadeh F, Dixon CE, Kochanek PM: The relationship between brain temperature and neutrophil accumulation after traumatic brain injury in rats. Acta Neurochir Suppl $\quad \mathbf{7 0}: 260-261,1997$.

51) $\mathrm{Xu} R X$, Nakamura $T$, Nagao $\mathrm{S}$, Miyamoto $\mathrm{O}$, Jin $\mathrm{L}$, Toyoshima $\mathrm{T}$, Itano $\mathrm{T}$ : Specific inhibition of apoptosis after cold-induced brain injury by moderate postinjury hypothermia. Neurosurgery 43: 107-114, 1998.

52) Yager JY, Asselin J: Effect of mild hyperthermia on cerebral energy metabolism during the evolution of hypoxic ${ }^{-}$ ischemic brain damage in the immature rat. Stroke 27 : 919-925, 1996. 
要 旨

頭部外傷に対する低体温療法の適応と限界

\section{末廣 栄一 藤澤 博亮 小泉 博靖 米田 浩 \\ 石原 秀行 野村 貞宏 藤井 正美 鈴木 倫保}

重症頭部外傷治療において低体温療法に代わる有効な治療法の出現はなく，本治療法の役割はいま だに大きい，その有効性を高めるためには，より早期の低体温療法への導入，あるいは低体温維持期 や復温期におけるモニタリング下での個々の病態に応じた適切な温度管理が必要である. 重症頭部外 傷の病態は多様であるが, 近年では急性硬膜下（外）血腫や脳挫傷など, 開頭術を要する病態での本 治療法の有効性が強調されてきている. 今後, 温度管理法や適応症例の見直しによる本治療法の成績 向上が期待される.

現在, 日本脳神経外科コングレス 65 歳以上の再入会について, 平成 24 年度から下記の条件にて再入会の手続きを進める方 向で準備しておりますことをご報告申し上げます（65 歳未満につきましては，継続審議中となっております）

なお, 詳細につきましては会則変更が必要のことから, 第 32 回日本脳神経外科コングレス総会以降となりますことをごア承く ださい.

ご不明な点は，コングレス事務局（jicns@juntendo.ac.jp）までお願い甲し上げます．

記

1） 65 歳以上の再入会に関して，入会金および年会費未納分も免除するが，再入会以降 70 歳まで年会費は支払ってい ただく.

2） 65 歳以上の一度もコングレスに入会したことのない方には，通常どおり新入会費および70 歳まで年会費を支払っ ていただく

3）70 歳以上のコングレス会員でジャーナル送付不要の申し出がない方は，脳神経外科ジャーナルを引き続き送付する (原則無料).

日本脳神経外科コングレス事務局

于113-8421 東京都文京区本郷 2-1-1

順天堂大学医学部脳神経外科内

TEL 03-3813-1039 FAX 03-5684-3096

http : //jcns.umin.jp/ E-mail : jons@juntendo.ac.jp 